\title{
PROGRAM PENINGKATAN KOMPETENSI DOSEN DI UNIVERSITAS JABAL GHAFUR
}

\author{
Diana Devi \\ Program Studi Bimbingan Konseling \\ Fakultas Keguruan dan Ilmu Pendidikan Universitas Jabal Ghafur. \\ Email: dianadevi31@yahoo.com
}

\begin{abstract}
Abstrak
Peningkatan kompetensi dosen merupakan salah satu usaha untuk meningkatkan kualitas dosen. Penelitian tentang Program Peningkatan Kompetensi Dosen di Universitas Jabal Ghafur telah dilaksanakan pada Bulan Mei sampai dengan Bulan Juni 2014. Tujuan penelitian ini adalah untuk mengetahui bagaimana pelaksanaan program peningkatan kompetensi bagi dosen di Universitas Jabal Ghafur.Narasumber terdiri dari Rekor, Dekan, Pembantu Dekan, para dosen dari program studi yang berbeda di lingkungan Unigha, dan staf Badan Jaminan Mutu Unigha. Penelitian ini bersifar deskriptif kualitatif, Pengumpulan data dilakukan melalui wawancara, kuisioner, dan dokumentasi. Hasil penelitian menunjukkan Pelaksanaan program peningkatan kompetensi dosen di Universitas Jabal Ghafur sudah dilaksanakan dengan baik;Bentuk-bentuk program peningkatan kompetensi dosen di Universitas Jabal Ghafur yang sudah dilaksanakan adalah meningkatkan kemampuan mengajar dosen melalui seminar, pelatihan dan workshop seperti pembuatan modul, penerapan model mengajar active learning dan student center learning. Short course ke sejumlah perguruan tinggi di dalam maupun di luar Aceh, serta program studi lanjut master dan doktoral.
\end{abstract}

Kata kunci;, Dosen, Kompetensi, Universitas Jabal Ghafur.

\section{Pendahuluan}

Perkembangan dunia yang begitu cepat menuntut sumber daya manusianya mampu bersaing dalam iklim yang sangat kompetitif seperti saat ini. Ini menunjukkan bahwapembangunan sumber daya manusia merupakan kebutuhan mutlak. Dalam menghasilkan sumber daya manusia yang unggul danberkualitas untuk menghadapi era globalisasi tidak terlepas dari peran pergutuan tinggi dalam menyiapkan lulusan yang mampu bersaing di tingkat nasional maupun internasional. Perguruan tinggi sebagai slah satu lembaga yang menjalankan pendidikan nasional mempunyai peran penting dalam menerapkan Tri Darma Perguruan Tinggi, yaitu pendidikan, penelitian , dan pengabdian kepada masyarakat. Hal ini sesuai dengan bunyi Undang-Undang RepublikIndonesia nomor 12 tahun 2012 tentang pendidikan tinggi, di dalam undang-undang tersebut di bagian kesembilan membahas tentang pendidikan, bagian kesepuluh membahas penelitian dan bagian kesebelas membahas tentang pengabdian kepada masyarakat.

Dosen merupakan salah satu kebutuhan penting bagi perguruan tinggi untuk menghasilkan lulusan yang berkualitas. Ia ibarat mesinpengggerak bagi segala hal yang terkait dengan aktivitas ilmiah dan akademis. Seorang dosen bukan saja hanya sebagai pendidik profesional pada perguruan tinggi tetapi juga sebagai ilmuwan. Tanpa dosen tak mungkin sebuah lembaga pendidikan di sebut perguruan tinggi atau universitas. Komponen sumber daya yang paling penting diberdayakan di perguruan tinggi adalah dosen, karena jika ingin menigkatkan prestasi dan kualitas institusi, maka memperbaiki dan meningkatkan kualitas dosen harus menjadi prioritas utama di sebuah perguruan tinggi (Janawi, 2012).

Seiring dengan persaingan yang semakin ketat antar universitas dalam hal peningkatan mutu akademik, maka tuntutan terhadap kualitas dosen terus ditingkatkan untuk melahirkan lulusan yang berkualitas, sehingga mampu bersaing di tingkat nasional dan internasional. Kompetensi dosen pada masa yang akan datang akan semakin berat, hal ini terjadi karena trend bisnis dan industri serta teknologi mulai merambah ke dunia pendidikan (Made, 2011). Oleh karena itu, dosen dituntut multi dispiplin, memiliki kompetensi kepribadian dan soft skill dalam menghadapi tantangan kerja. Kompetensi adalah kecakapan dan kemampuan. Menurut Echols dan Shadly (Musfah 2012): Kompetensi 
adalah kumpulan pengetahuan, prilaku, dan keterampilan yang harus dimiliki guru untuk mencapai tujuan pembelajaran dan pendidikan.

Sehubungan dengan permasalahan di atas maka penulis tertarik untuk mengkaji lebih jauh tentang"Program Peningkatan Kompetensi dosen di Universitas Jabal Ghafur. Penelitian ini bertujuan untuk mengetahui bagaimana pelaksanaan program peningkatan kompetensi bagi dosen di Universitas Jabal Ghafur.

\section{Prosedur Penelitian}

Penelitian ini adalah penelitian deskriptif dengan menggunakan pendekatan kualitatif. Penelitian dilakukan di Universitas Jabal Ghafur pada Bulan Mei sampai dengan Juni Tahun 2014. Subjek dalam penelitian ini adalah Rektor, pembantu dekan, dosen, dan staf LPPM.Instrumen yang dipakai dalam penelitian ini adalah pedoman wawancar dan lembar observasi. Data dikumpulkan melalui wawancara, observasi dan dokumentasi. Data yang diperoleh selanjutnya dianalisis dengan menggunakan teknik analisis kualitatif yairu: (a) reduksi alat; dari data yang sudah terkumpul penulis akan mengelompokkan menurut indikatoir-indikator pengolahan data. (b) display data, data baru akan diolah setelah display data. (3) mengambilkesimpulan atau verifikasi, dari hasil analisis data.

\section{Hasil penelitian dan pembahasan}

Pendidikan dan pengajaran

Untuk meningkatkan kompetensi dosen di Universitas Jabal Ghafur, dilakukan berbagai pelatihan, seminar, workshop yaitu:

1) Pelatihan Penerapan Metode

Pembelajaran Student Centered Learning (SCL)

2) Pelatihan Standart Operational Procedure

3) Workshop Pembuatan Modul Pembelajaran

4) Workshop Pembuatan proposal penelitian

5) Short course ke Universitas Negeri Surabaya dan Universitas Negeri Semarang, dan Universitas Negeri Yogyakarta.

Pelatihan merupakan salah satu usaha dalam menigkatkan kompetensi dosen. Pelatihan merupakan kegiatan utnuk menciptakan tenaga yang terampil baik yang dilakukan oleh individu, lembaga, dan kelompok. Menurut Flippo dam Harun (2009) " training is the act of increasing the knowledge and skills of an employee of doing the particular job", dari apa yang dikemukakan Flippo tersebut jelaslah bahwa pelatihan memiliki pengaruh besar terhadap penigkatan kompetensi khusunya dosen di perguruan tinggi.

Hasil wawancara yang diperoleh peneliti dari beberapa dosen dapat disimpulkan bahwa berbagai kegiatan akademis yang telah dilaksanakan tersebut sangat bermanfaat untuk meningkatkan kualitas mereka, namun mereka masih mebutuhkan pelatihan-pelatihan dan program serupa lainnya yang berkelanjutan agar dapat menyeimbangi ilmu pengetahun yang selalu berkembang. Hal ini memang sudah menjadi agenda rutin Universitas Jabal Ghafur, karena sesuai dengan yang dikemukakan Lieberman (2012) bahwa pelatihan yang diberikan kepada dosen hanya sekali saja atau pelatihan yang ringkas, maka besar kemungkinan tidak akan efektif.

Selain itu dorongan untuk melakukan studi lanjut bagi dosen-dosen juga terus digalakkan. Sejumlah dosen di lingkungan unigha sedang studi lanjut di berbagai universitas baik di dalam maupun di luar Aceh, untuk program master maupun doktoral. Untuk menigkatkan kualitas ilmu pengetahuan dan teknologi dan pembangunan, diperluakn kualitas dosen yang memadai, karenanya jenjang pendidikan lanjutan bagi dosen (S2 dan S3) perlu selalu dimaysrakatkan. Hal ini sesuai dengan mandate Undang-Undang Republik Indonesia Nomor 14 Tahun 2015 tentang Guru dan Dosen, pasal 45 yang berbunyi "Dosen wajib memiliki kualifikasi akademik, kompetensi, sertifikat pendidikan, sehat jasmani dan rohani, dan memenuhi kualifikasi lain yang dipersyaratkan satuan pendidikan tinggi tempat bertugas, serta memiliki kemampuan untuk mewujudkan tujuan pendidikan nasional".

Hasil penelitian juga menunjukkan bahwa pelaksanaan program penigkatan kompetensi dosen tidak hanya terfokus pada program studi lanjut dan pelatihan serta kegiatan serupa lainnya, upaya lain seperti membangun kerjasama dengan lembaga pendidian tinggi lain seperti dengan Universitas Syiah Kuala Banda Aceh, Universitas Malikul Saleh Lhokseumawe, Universitas Gajah Putih Takengon, USAID PRIORITAS Aceh dan Universiti Malaya, Malaysia dan Academies Australasia College di Singapura, sudah dilaksanakan.

Selain itu berbagai program kerjasama dalam bidang pendidikan sudah dijalin melalui penandatanganan Nota Kesepakatan Kerjasama dengan beberapa lembaga, seperti program 
magang bagi staf Badan Jaminan Mutu(BJM) dan staf perpustakaan Universitas Jabal Ghafur di Universitas Syiah Kuala. Sosialisasi program kurikulum 2013, bekerjasama dengan USAID Prioritas Aceh.

Program yang berkaitan dengan bidang pertanian, ilmu adminstrasi, ekonomi dan hukum juga sudah terjalin dengan Universitas Malikul Saleh, Lhokseumawe. Program Joint Research, seminar internasional, student exchange dan studi lanjut (S2dan S3) bagi dosen Universitas Jabal Gafur telah dijalin dengan Universiti Malaya di Malaysia. Kerjasama ini dapat menigkatkan dan menambah pengetahuan dosen, sehingga pengalaman dan kualitas mereka dapat meningkat.

Program pengembangan pengajaran berbasis teknologi informasi telah dilaksanakan dengan memberdayakan dan meningkatkan penggunaan fasilitas akademik terutama elektronik untuk mempercepat proses transformasi informasi. Hasil observasi di lapangan menunjukkan bahwa lebih dari $80 \%$ dosen di Universitas Jabal Ghafur menggunakan laptop dan projector pada saat mengajar. Hal ini ditegaskan oleh dosen yang diwawancarai oleh peneliti: "penggunaan laptop dan projector pada saat mengajar dapat memudahkan dosen menjelaskan materi kuliah kepada mahasiswa dan sebaliknya mahasiswa dapat melihat lansgung poin per poin yang akan dijelaskan".

Pengawasan Program Peningkatan Kompetensi Dosen

Program yang sudah dilaksanakan haruslah dilakukan pengawasannuntuk melihat apakah program tersebut sudah sesuai dengan apa yang diharapkan oleh sebuah lembaga (Fattah, 2013). Jika sistem pengawasan di dalam suatu lembaga lemah, maka hasil yang akan didapatkan akan juga lemah. Fattah (2013) lebih lanjut menambahkan akibat lemahnya pengawasan dalam suatu organisasi terjadilah berbagai penyimpangan dalam pelaksanaan program yang sudah direncanakan. Pengawasan terhadap pelaksanaan program peningkatan kompetensi dosen di Universitas Jabal Ghafur dilakukan oleh Badan Jaminan Mutu, baik di tingkat Universitas dan juga di tingkat Fakultas. Berdasarkan hasil wawancara peneliti, Rektor mengatakan:" monitoring dan evaluasi dilakukan kepada semua dosen yang mengajar di Universitas Jabal ghafur. Kegiatan ini dilakukan pada setiap akhir semester oleh BJM Universitas
Jabal Ghaur, terkait dengan badan ini yang memiliki beberapa divisi yaitu divisi akademik, divisi akreditasi, dan divisi monitoring dan evaluasi".Proses monitoring dan evaluasi yang dilakukan oleh BJM ini dengan cara membagikan kuisioner kepada mahasiswa untuk mendapatkan umpan balik terhadap kinerja dosen mereka. Hasil monitoring dan evaluasi tersebut kemudian dirangkum dan dijadikan sebuah laporan. Laporan tersebut diserahkan kepada Rektor untuk selanjutnya menindaklanjuti saran-saran dan rekomendasi yang diberikan oleh BJM.

\section{Kesimpulan}

1. Pelaksanaan program peningkatan kompetensi dosen di Universitas Jabal Ghafur sudah dilaksanakan dengan baik;

2. Bentuk-bentuk program peningkatan kompetensi dosen di Universitas Jabal Ghafur adalah berbagai seminar, workshop, pelatihan, short course serta studi lanjut.

3. Pengawasan terhadap pelaksanaan program peningkatan kompetensi dosen di Universitas Jabal Ghafur dilakukan oleh Badan Jaminan Mutu, baik di tingkat Universitas maupun Fakultas.

\section{Daftar Pustaka}

Fattah, Nanang (2013). Landasan Manajemen Pendidikan. Bandung. PT. Remaja Rosda Karya.

Harun, Cut Zahri (2009). Manajemen Sumber Daya Manusia. Yogyakarta. Pena Persada Dekstop Publiser.

Janawi (2012). Kompetensi Guru. Citra Guru Profesional. Bandung. Alfabeta.

Musfah, Jejen (2012). Peningkatan Kompetensi Guru Melalui Pelatihan dan Sumber Belajar Teori dan Praktik. Jakarta. CV. Kencana.

Sugiyono (2013). Cara Mudah Menyusun Skripsi, Thesis, dan Disertasi. Bandung. Alfabeta.

Undang-Undang Republik Indonesia Nomor 14 Tahun 2005 Tentang Guru dan D 